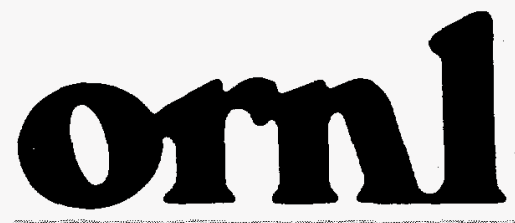

OAK RIDGE NATIONAL LABORATORY
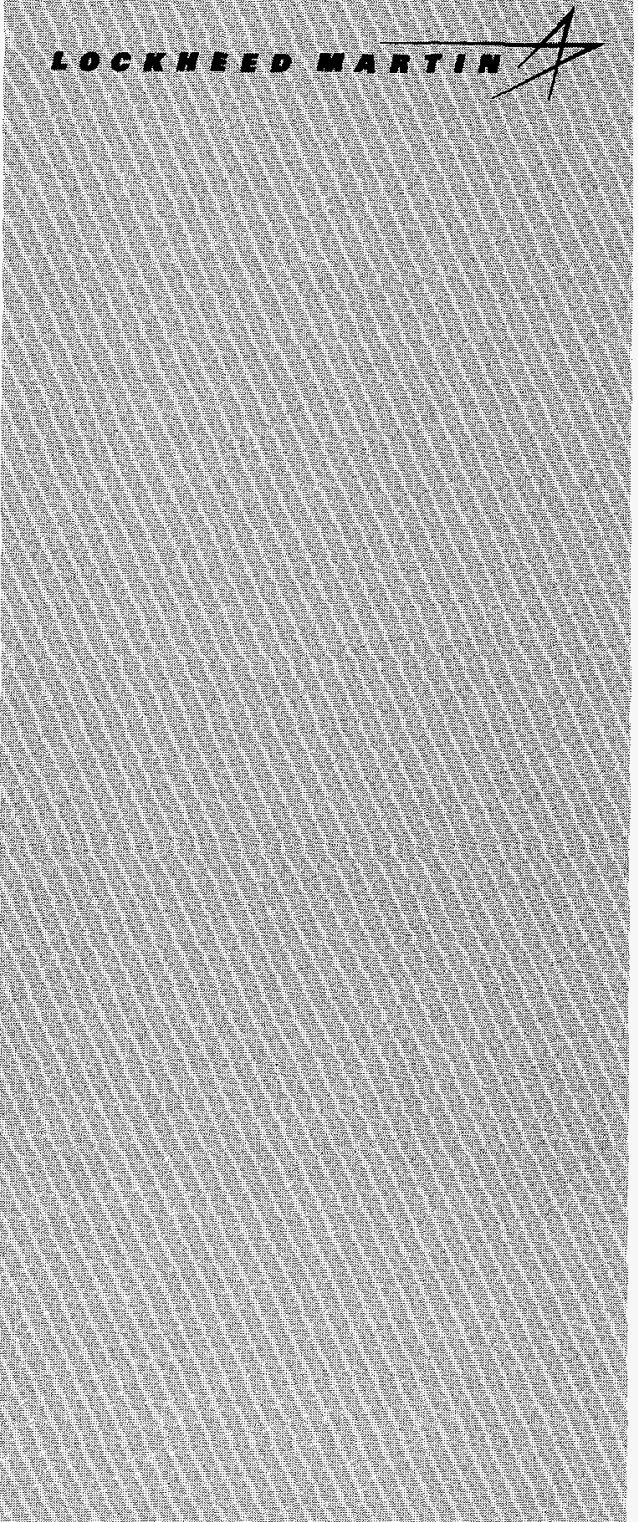

WHMGEO AND OPERMTED BY LOCKHEED WARTN ENERGY RESEARCH CORPORATION FOR THE UNTED STATES DEPARTMEIT OF ENERGY

\section{ORNL/TM-13425}

\section{Cost Estimate and Economic Issues Associated With the MOX Option (Prior to DOE's Record of Decision)}

\author{
R. L. Reid \\ J. W. Miller \\ RECEIVED \\ MAR 12 198 \\ $0 \mathrm{ST}$
}


This report has been reproduced directly from the best available copy.

Available to DOE and DOE contractors from the Office of Scientific and Technical Information, P.O. Box 62, Oak Ridge, TN 37831; prices available from (423) 576-8401.

Available to the public from the National Technical Information Service, U.S. Department of Commerce, 5285 Port Royal Rd., Springfield, VA 22161.

This report was prepared as an account of work sponsored by an agency of the United States Government. Neither the United States Government nor any agency thereof, nor any of their employees, makes any warranty, express or implied, or assumes any legal liability or responsibility for the accuracy, completeness, or usefulness of any information, apparatus, product, or process disclosed, or represents that its use would not infringe privately owned rights. Reference herein to any specific commercial product, process, or service by trade name, trademark, manufacturer, or otherwise, does not necessarily constitute or imply its endorsement, recommendation, or favoring by the United States Government or any agency thereof. The views and opinions of authors expressed herein do not necessarily state or reflect those of the United States Government or any agency thereof. 


\section{DISCLAIMER}

Portions of this document may be illegible electronic image products. Images are produced from the best available original document. 
ORNL/TM-13425

Dist. Category UC-523

\title{
COST ESTIMATE AND ECONOMIC ISSUES ASSOCIATED WITH THE MOX OPTION (PRIOR TO DOE'S RECORD OF DECISION)
}

\author{
R. L. Reid \\ J. W. Miller
}

Date Published: April 1997

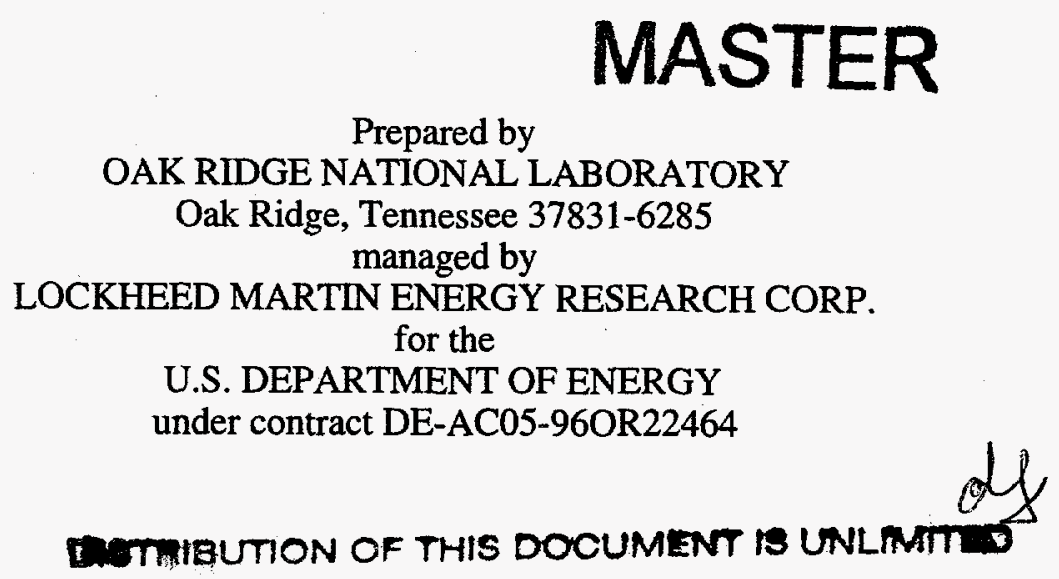


Page Intentionally Blank 


\section{CONTENTS}

Page

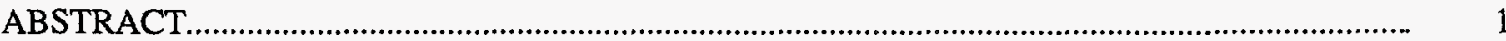

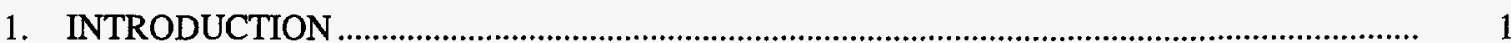

2. SUMMARY OF THE REACTOR ALTERNATIVE LIFE-CYCLE COSTS DEVELOPED

FOR THE ROD

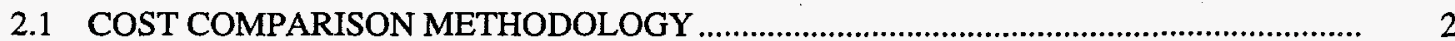

2.1.1 Investment and Startup Cost ....................................................................................... 2

2.1.2 Total Life-Cycle Cost ...................................................................................... 2

2.1.3 Ensuring Equality for Economics Analysis Among All Options ................................ 2

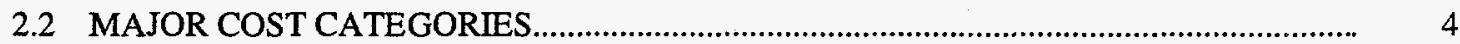

2.2.1 TPC (Investment Plus Startup Costs) …................................................................... 4

2.2.2 Recurring Costs.....................................................................................................

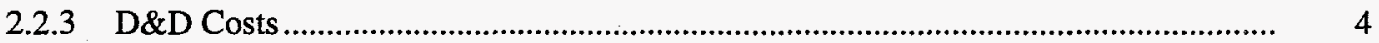

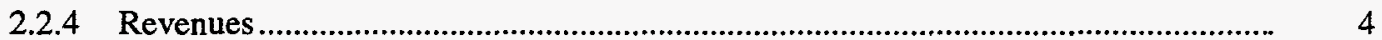

2.3 GENERAL ASSUMPTIONS FOR THE PLUTONIUM DISPOSITION

ALTERNATIVE COST ESTIMATES …....................................................................... 4

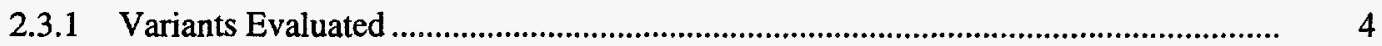

2.3.2 Facility Requirements ..................................................................................... 5

2.3.3 Discounting Assumptions ............................................................................... 5

2.3.4 Ownership Assumptions .......................................................................................... 5

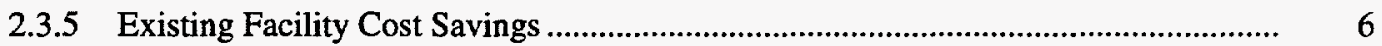

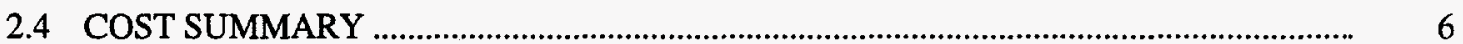

3. COST UNCERTAINTIES IDENTIFIED BEFORE ROD.......................................................

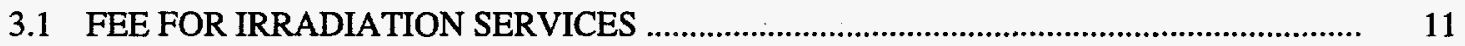

3.2 REACTOR MODIFICATIONS ….................................................................................. 11

3.3 VARIATION IN THE MARKET PRICE FOR LEU FUEL ..................................................

3.4 HIGH-LEVEL WASTE REPOSITORY ......................................................................... 11

3.5 ADVERSE VARIATION IN FRONT-END PROCESS PARAMETERS ............................... 12

3.6 MODIFICATION AND CONSTRUCTION COSTS ...................................................... 12

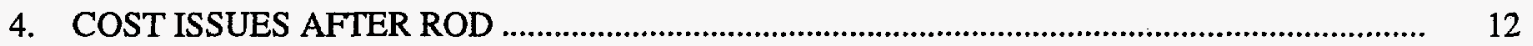

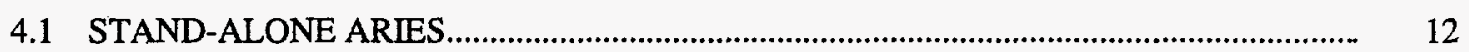

4.2 COST ACCOUNTING FOR GOVERNMENT (IMMOBILIZATION) vs PRIVATE (MOX) PROJECT ........................................................................................... 12

4.3 EFFECTS OF OMB CIRCULAR A-11 REVISION (FULL UP-FRONT FUNDING

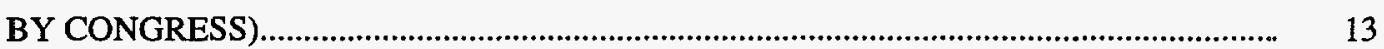

4.4 FINANCIAL CRITERIA OF IMPORTANCE IN SELECTING A CONSORTIUM ............ 13

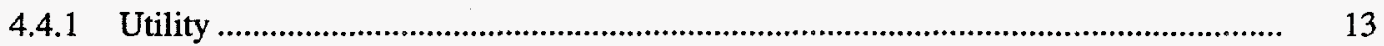

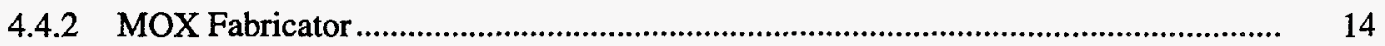

5. DEVELOPMENT OF NEW COST ESTIMATES FOR MOX FABRICATION

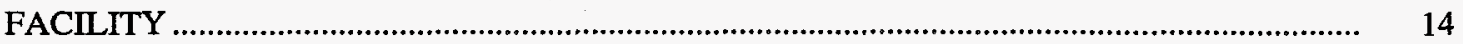

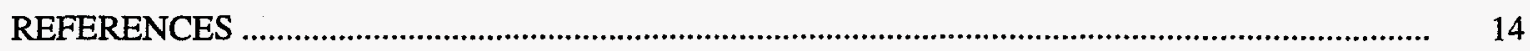

APPENDIX A: EXPLANATION OF 24 COST CATEGORIES ….....................................................

APPENDIX B: HOW TO OBTAIN SELECTED DOCUMENTS ...................................................... 
Page Intentionally Blank 


\title{
COST ESTIMATE AND ECONOMIC ISSUES ASSOCIATED WITH THE MOX OPTION (PRIOR TO DOE'S RECORD OF DECISION)
}

\author{
R. L. Reid \\ J. W. Miller
}

\begin{abstract}
Before the January 1997 Record of Decision (ROD), the U.S. Department of Energy Office of Fissile Materials Disposition (DOE-MD) evaluated three technologies for the disposition of $\sim 50 \mathrm{MT}$ of surplus plutonium from defense-related programs-reactors, immobilization, and deep boreholes. As part of the process supporting the ROD, a comprehensive assessment of technical viability, cost, and schedule was conducted by DOE-MD and its national laboratory contractors. Oak Ridge National Laboratory managed and coordinated the life-cycle cost (LCC) assessment effort for this program. This report discusses the economic analysis methodology and the results for the reactor options considered prior to ROD. A secondary intent of the report is to discuss major technical and economic issues that impact cost and schedule.

To evaluate the economics of the reactor option and other technologies on an equitable basis, a set of cost-estimating guidelines and a common cost-estimating format were utilized by all three technology teams. This report includes the major economic analysis assumptions and the comparative constant-dollar and discounted-dollar LCCs for all nine reactor scenarios.
\end{abstract}

\section{INTRODUCTION}

This report addresses the history of the economic issues associated with the mixed-oxide (MOX) reactor option (the immobilization and borehole alternatives are not discussed here). It provides a summary of the economics work on this option before the U.S. Department of Energy's (DOE's) Record of Decision (ROD). This record is not a part of the program acquisition strategy; however, it is provided to give potential bidders some insight into how the MOX option cost estimates were prepared. Prior to ROD, the reactor option's projected mission was to dispose of $50 \mathrm{MT}$ of plutonium through the burning of MOX fuel in water reactors, either existing reactors [The Canadian uranium-deuterium reactor (CANDU) or light-water reactors (LWRs)], new evolutionary LWRs, or partially completed LWRs. This report will be structured as follows. First, the life-cycle costs (LCCs) for seven candidate reactor concepts and two hybrid reactor/immobilization concepts considered in ROD for burning the excess plutonium will be summarized. Constant-dollar and discounted-dollar LCCs are considered. Second, cost uncertainties inherent in the LCC analysis will be discussed, including those raised by opponents of the MOX option. Third, new cost issues that have arisen since the ROD will be discussed. The third section also considers new issues raised by the hybrid implementation option, in which $33 \mathrm{MT}$ instead of $50 \mathrm{MT}$ of plutonium will be dispositioned by the MOX option.

The reactor option is technically mature as evidenced by the use of MOX fuel in Europe. The implementation of MOX made from weapons-usable plutonium in the United States has many institutional and political issues that heavily impact cost and schedule. Among these are the following: (1) type of reactors; (2) ownership of the MOX fuel facilities; (3) the licensing process; (4) monetary or other incentives to utility-reactor owners required for utility participation; (5) public acceptance of MOX transportation and use; and (6) the future market for electrical energy generated by nuclear power and the potential for revenues to offset plutonium disposition costs (for government-owned reactors only). The first of these issues was addressed in the recent January 1997 ROD with the selection of the existing LWR option for the preferred reactor/MOX path. 


\section{SUMMARY OF THE REACTOR ALTERNATIVE LIFE-CYCLE COSTS DEVELOPED FOR THE ROD}

\subsection{COST COMPARISON METHODOLOGY}

A goal of the Fissile Materials Disposition Program (FMDP) is to minimize the incremental cost impact to the government and taxpayers. Although the national security benefits clearly outweigh the costs involved, significant budget pressures are projected throughout program execution. Timing and allocation of costs were assessed in the pre-ROD studies. The following cost-related performance factors or figures of merit were considered in evaluating the extent to which a particular reactor configuration variant was cost effective.

\subsubsection{Investment and Startup Cost}

Investment and startup cost refers to research and development (R\&D), regulatory, construction, retrofit, and program infrastructure costs that are incurred early in the program. In government accounting, the sum of these is the total project cost (TPC).

\subsubsection{Total Life-Cycle Cost}

Large government projects, such as those proposed by FMDP, must consider not only design and construction costs but also the costs to operate the facilities and to safely decontaminate and decommission (D\&D) them. For this reason, the total life-cycle cost (TLCC) approach was used for cost estimating to obtain the true "cradle to grave" costs. This costing methodology also made comparison of competing plutonium disposition alternatives more meaningful. Some of the reactor alternatives under consideration had different operating lifetimes, and the use of TLCC allowed schedule differences (which affect cash flows) to be correctly reflected in the overall costs.

TLCC included adjustments for revenues that may be produced by electric power production or sales of fuel but did not include the sunk (before FY 1997) costs of existing facilities or other costs that would be incurred whether or not any action on plutonium disposition was taken. When the constant dollar cash flows were discounted year by year, and the resulting net present value (NPV) sums were added, a discounted total life-cycle cost (DTLCC) was obtained. This figure of merit is often preferred because it takes into account the time value of money.

\subsubsection{Ensuring Equality for Economic Analysis Among All Options}

Early in the FMDP evaluation process, a set of cost-estimating guidelines and a 24-category LCC estimating format were established for both the reactor and nonreactor options (immobilization and borehole) (Table 1). This was done to ensure comparability between estimates and to assist in the decision-making process. An explanation of each of the 24 cost categories is included in Appendix A. The various reactor and nonreactor candidate estimates were then reviewed for completeness and adherence to the guidelines. Much of the reactor cost data came from 1993 and 1994 plutonium disposition feasibility studies by reactor vendors; reactor cost data bases at Oak Ridge National Laboratory (ORNL); DOE plutonium-handling sites, such as the Savannah River Site (SRS); and the two weapons research laboratories [Lawrence Livermore National Laboratory (LLNL) and Los Alamos National Laboratory (LANL)] and their architectengineer (A-E) subcontractors. The FMDP multilaboratory Systems Analysis Team had the role of "levelizing" the cost data (i.e., ensuring their comparability). Note that the focus in these studies was the TLCC to the federal government and, specifically, those costs that will be borne by DOE-MD. Costs to private concerns such as utilities, fuel suppliers, and others were not the focus of this study; however, they may have been used during the estimating process to calculate costs that would be ultimately passed on to DOE-MD. (An example would be the cost of MOX fuel from a privately owned fabrication facility specifically built to meet government plutonium disposition needs.) 
Table 1. LCC estimate 24-category format ${ }^{a}$

\begin{tabular}{|c|c|}
\hline Category & Cost category description \\
\hline & Preoperational or OPC up-front costs: \\
\hline 1 & $\mathrm{R} \& \mathrm{D}$ \\
\hline 2 & NEPA, licensing, permitting \\
\hline 3 & Conceptual design \\
\hline 4 & Implementation plans: QA, site qualification, S\&S \\
\hline 5 & Postconstruction start-up \\
\hline \multirow[t]{3}{*}{6} & Risk contingency \\
\hline & Total of categories $1-6(\mathrm{OPC})$ \\
\hline & Capital or TEC up-front costs: \\
\hline 7 & Title I, II, III engineering, design, and inspection \\
\hline $8 a$ & Capital equipment \\
\hline $8 b$ & Direct and indirect construction/modification \\
\hline 9 & Construction management \\
\hline 10 & Initial spares (technology dependent) \\
\hline 11 & Allowance for indeterminates (AFI) \\
\hline \multirow[t]{4}{*}{12} & Risk contingency \\
\hline & Total of categories $7-12$ (TEC) \\
\hline & TOTAL INVESTMENT OR UP-FRONT COST $($ TPC $=$ OPC + TEC $)$ \\
\hline & Other LCCs: (recurring) \\
\hline 13 & O\&M staffing \\
\hline 14 & Consumables including utilities \\
\hline 15 & Major capital replacements or upgrades \\
\hline 16 & Waste handling and disposal \\
\hline 17 & Oversight \\
\hline 18 & $\mathrm{M} \& \mathrm{O}$ contractor fees \\
\hline \multirow[t]{3}{*}{19} & PILT to local governments \\
\hline & TOTAL RECURRING COSTS (sum of categories 13-19) \\
\hline & Other LCCs: \\
\hline 20 & D\&D \\
\hline 21 & Revenues (if applicable) \\
\hline 22 & Fees to privately owned facility \\
\hline 23 & Transportation of plutonium forms to facility \\
\hline \multirow[t]{3}{*}{24} & Storage of plutonium at existing DNFSB 94-1 site facility \\
\hline & TOTAL OTHER LCC (sum of categories 13-24) \\
\hline & GRAND TOTAL ALL LCC (sum of TPC + other LCCs in $1996 \$$ ) \\
\hline
\end{tabular}

$a_{\text {Note: }}$ S\&S = safeguards and security $\mathrm{M \& O}=$ management and operating $\mathrm{OPC}=$ operating-funded project cost NEPA $=$ National Environmental Policy Act TEC $=$ total estimated cost TPC $=$ total project cost (same as up-front cost)
$\mathrm{QA}=$ quality assurance

PILT = payments in lieu of taxes

$\mathrm{D} \& \mathrm{D}=$ decontamination and decommissioning

DNFSB $=$ Defense Nuclear Facilities Safety Board 


\subsection{MAJOR COST CATEGORIES}

The 24 categories shown in Table 1 can also be presented in a different manner to represent the phases of a project plus one additional category that represents the possibility of a return revenue stream during the project.

\subsubsection{TPC (Investment Plus Startup Costs)}

TPC is essentially the sum of the up-front costs needed to bring a facility into full-capacity operation as discussed in Sect. 2.1. This includes planning, R\&D, environmental safety and health (ES\&H) studies [including the National Environmental Policy Act (NEPA)], site qualification, quality assurance planning, permitting, licensing, safety analysis, design, construction, project management, initial spare equipment items, facility startup, staff training, the operational readiness review, and manual preparation.

\subsubsection{Recurring Costs}

Recurring costs are incurred during normal facility operation after startup and include plant staffing costs (including fringe benefits and taxes), costs of process consumables and maintenance materials, utility costs, administrative and plant overheads, transportation costs for nuclear materials, oversight costs, fees to the facility management contractor, capital replacement items, waste-handling costs, and payments in lieu of taxes to local communities.

\subsubsection{D\&D Costs}

These are the costs incurred at facility end of life to decommission and remove process equipment and to decontaminate any process buildings to a safe or habitable state where no adverse human health or environmental consequences result. For this study it was not deemed necessary to restore the site to greenfield status.

\subsubsection{Revenues}

A special category is that of revenues. For some of the reactor alternatives considered (i.e., those for which the government owns the reactor and/or the MOX fabrication facility), the federal government may benefit from the sale of the following items:

- Electricity: If the government owns the nuclear power plant, electricity will be sold on the wholesale market.

- MOX fuel: If the government owns the MOX fuel fabrication facility and provides MOX fuel bundles to a private utility reactor owner, the government is credited for the MOX at a price close to that of the energy-equivalent amount of low enriched uranium (LEU) fuel displaced by the MOX (i.e., a LEU fueldisplacement credit).

- Reactor power plant salvage value: If the government owns the nuclear power plant during the duration of the plutonium disposition campaign, it may wish to sell the plant to a utility at the end of the campaign, thus removing the government from the business of selling electricity without an accompanying national security mission.

\subsection{GENERAL ASSUMPTIONS FOR THE PLUTONIUM DISPOSITION ALTERNATIVE COST ESTIMATES}

\subsubsection{Variants Evaluated}

To support the January 14, 1997, ROD, the following seven reactor-only and two hybrid (reactor plus immobilization) configuration candidates were examined: 
1. Two partially complete LWRs.

2. Two to four existing CANDU heavy-water reactors (HWRs).

3. Five existing utility-owned pressurized-water reactors (PWRs) with a government-owned MOX fabrication facility.

4. Five existing utility-owned PWRs with a privately owned MOX fabrication facility.

5. Four existing utility-owned boiling-water reactors (BWRs) with a collocated plutoniumprocessing/MOX fabrication facility.

6. Five existing utility-owned PWRs with both domestic and European MOX fabrication. (Allows plutonium disposition to start prior to completion of U.S. MOX plant, or Quick Start.)

7. Two new evolutionary PWRs with government MOX fabrication.

8. Hybrid: Three PWRs (32.5-MT plutonium) plus can-in-canister (17.5-MT plutonium) vitrification.

9. Hybrid: Two CANDU reactors (32.5-MT plutonium) plus can-in-canister (17.5-MT plutonium) vitrification.

The facility requirements, technical viability, schedules, and costs associated with the above reactor configurations were discussed in the reactor alternative summary reports (RASRs) issued by the reactor team ${ }^{1-4}$ and the Technical Summary Report ${ }^{5}$ issued by DOE-MD. This report summarizes the LCCs estimated for each of these reactor variants. Some of the basic assumptions for development of the estimates are discussed below. The costs shown in this report for the reactor cases are consistent with those in the RASRs and include business-related costs that are not in Ref. 5, such as fees paid to utilities.

\subsubsection{Facility Requirements}

For all cases, LCCs were calculated by facility. Two or more facilities are needed to complete the total end-to-end plutonium disposition project. It is assumed that the process starts with metal plutonium weapons parts ("pits") or other stable and packaged forms such as alloys or oxides. The end state is isolation of the plutonium form from the environment in a geologically stable location. If the form is physically accessible, it must meet the Spent Fuel Standard (SFS) as defined in the National Academy of Sciences plutonium disposition study. ${ }^{6}$

Facilities were classified as either front-end or back-end. For the reactor options, the front-end facilities were the plutonium-processing (PuP) facilities that convert the plutonium feed forms to a plutonium oxide powder suitable for the next front-end facility, the MOX fabrication facility. Back-end facilities were those that do the real disposition task. For the reactor options, they were the reactors and the geologic repository that accepts the spent MOX fuel.

\subsubsection{Discounting Assumptions}

The total discounted dollar cost was calculated by spreading the government's constant-dollar cash flows in a manner consistent with the project schedule, and then discounting these cash flows at $5 \%$ real discount rate as acceptable to the Office of Management and Budget (OMB). This discount rate is consistent with the federal government's costs of borrowing.

\subsubsection{Ownership Assumptions}

For most of the scenarios considered, the facilities were assumed to be owned by the government. The main exception was a possible private MOX fabrication facility and utility-owned commercial reactors whose owners were assumed to be compensated for their irradiation services. Government-owned facilities were assumed to be operated and managed by private corporations on a fee basis. The management and operations (M\&O) contractors' annual fee for the plutonium processing and the MOX fuel fabrication facility was calculated as $2 \%$ of the annual recurring costs. For the sake of this study, a private LWR reactor operator was assumed to receive a fee of $\$ 25$ million per reactor pair per year for the first 5 years of the plutonium disposition mission, followed by $\$ 10$ million per reactor pair per year thereafter (reflecting decreasing financial risk after 5 successful years). This fee assumption was not based on any actual 
DOE/utility negotiations and was included in the RASRs mainly to recognize the possibility of a fee-type arrangement for the reactor options.

\subsubsection{Existing Facility Cost Savings}

Many of the options could benefit economically from the use of existing facilities or buildings at DOE sites already having a plutonium-handling infrastructure, such as transuranic (TRU) waste facilities, Perimeter Intrusion Detection and Assessment System (PIDAS) fences, a trained security force, and analytical laboratories. All except the CANDU reactor assumed that a government geologic high-level waste repository would be available to accept the spent fuel forms or the waste canisters from the U.S. reactor or immobilization options, respectively. The candidate site for the first such repository to be located on government land is the Yucca Mountain Project in Nevada.

\subsection{COST SUMMARY}

All costs presented below are costs to the government and are in 1996 constant dollars unless otherwise noted.

Table 2 shows a comparison of LCCs for all of the reactor alternatives, which includes fees, electricity revenues, and MOX sales revenues (or fuel displacement credit) where appropriate. (MOX is supplied by DOE-MD to private reactor owners at an energy-equivalent price for a corresponding amount of LEU, or natural uranium for CANDU fuel.) Table 3 shows a similar comparison of LCCs for the two hybrid configurations, in a slightly different format. Figures 1 and 2 summarize in graphical form the constant-dollar and discounted LCCs for all the reactor and hybrid candidates.

The evolutionary reactor option requires the highest up-front cost (approximately $\$ 6.9$ billion) to the government. Prior to ROD, DOE indicated that they were unwilling to make a large investment that also puts them in the power production business. In constant dollars, the partially complete reactor option's LCC appeared very promising (mainly because of the revenues); but it also requires a large initial cost to the government to complete the reactor. [Information from the Tennessee Valley Authority's (TVA's) partially completed Bellefonte Plant was used to develop this estimate.]

Of all the existing LWR variants, the five-PWR base case has the lowest overall cost. The private MOX fuel fabrication facility case has lowest up-front cost to the government; however, the overall LCC is higher because of the interest and investment returns required for total privatization of the MOX fuel fabrication facility enterprise. With new PuP and new greenfield MOX collocated facilities, the four-BWR case has the highest up-front cost. This is due to the use of new front-end facilities rather than the use of BWRs vis-à-vis PWRs. The overall LCC, however, is only $\$ 200$ million greater than the five-PWR base case. The schedule advantages of the five-PWR Quick-Start case comes at a cost of only $\$ 205$ million over the base case (schedule data are in Refs. 1-4). Compared to existing LWRs, the CANDU existing reactor option suffers economically from two factors: (1) CANDU natural uranium fuel has a very low unit cost compared to LEU fuel; thus, the credit to DOE for uranium fuel displaced is nearly an order of magnitude smaller, and (2) the heavy-metal throughput associated with a CANDU MOX fabrication plant is much larger than for a LWR MOX fuel plant; thus, MOX facility LCCs could be larger.

The hybrid configurations have slightly higher LCCs than their pure reactor or pure vitrification counterparts, due to the dual requirements of both fabricating and burning the MOX in a reactor (32.5-MT plutonium) and also providing the capacity to vitrify and bury the remaining 17.5-MT plutonium. As an example, the five-PWR base case LCC is $\$ 2.224$ billion (Table 2) compared to the LWR hybrid LCC of $\$ 2.367$ billion (Table 3). However, this cost penalty for the hybrid may very well be compensated for by schedule, political, and performance assurance advantages of the hybrid compared to the pure reactor or pure immobilization options. In fact, the recent ROD signed by DOE has selected a dual-track strategy. The MOX portion of the hybrid would disposition the plutonium contained in clean metals and oxides, mostly weapon pits, and the immobilization portion of the hybrid would disposition the less pure plutonium forms found in alloys, residues, and other forms. 
Table 2. Comparison of LCCs for reactor variants

\begin{tabular}{|c|c|c|c|c|c|c|c|}
\hline \multirow[b]{2}{*}{ Cost category description } & \multicolumn{5}{|c|}{ Utility-owned reactors } & \multicolumn{2}{|c|}{ Government-owned reactors } \\
\hline & $\begin{array}{c}\text { Five existing } \\
\text { PWR base case } \\
\text { with government } \\
\text { MOX fabrication }\end{array}$ & $\begin{array}{c}\text { Five existing } \\
\text { PWR base case } \\
\text { with private } \\
\text { MOX } \\
\text { fabrication } \\
\end{array}$ & $\begin{array}{l}\text { Four existing } \\
\text { BWR case } \\
\text { with new } \\
\text { collocated } \\
\text { PuP/MOX }\end{array}$ & $\begin{array}{l}\text { Five existing } \\
\text { PWR base case } \\
\text { with Quick Start } \\
\text { (European and } \\
\text { U.S. government } \\
\text { MOX fabrication) } \\
\end{array}$ & $\begin{array}{l}\text { Existing } \\
\text { CANDU case } \\
\text { ( } 2 \text { to } 4 \text { units } \\
\text { with U.S. } \\
\text { government } \\
\text { fabrication) }\end{array}$ & $\begin{array}{l}\text { Two partially complete } \\
\text { PWRs with government } \\
\text { MOX fabrication } \\
\text { (revenues @ } \\
29 \text { mills/kWh) }\end{array}$ & $\begin{array}{l}\text { Two new evolu- } \\
\text { tionary PWRs with } \\
\text { government fabri- } \\
\text { cation (revenues @ } \\
29 \text { mills/kWh) }\end{array}$ \\
\hline & \multicolumn{7}{|c|}{ Undiscounted costs (constant 1996 \$M) } \\
\hline Up-front (investment) cost for all facilities & 954 & 554 & 1378 & 980 & 871 & 3054 & 6876 \\
\hline $\begin{array}{l}\text { Operations costs including transportation for } \\
\text { all facilities }\end{array}$ & 1995 & 1075 & 2114 & 1855 & 2292 & 4284 & 4663 \\
\hline D\&D costs for all relevant facilities & 229 & 169 & 456 & 229 & 239 & 371 & 248 \\
\hline Fee to reactor owners or contracted operators & 433 & 433 & 482 & 515 & 269 & 235 & 215 \\
\hline $\begin{array}{l}\text { Revenues from sale of MOX to privately } \\
\text { owned utility at uranium equivalent price }\end{array}$ & -1387 & -1387 & -2006 & -1387 & -320 & 0 & 0 \\
\hline Payment for EuroMOX fabrication & 0 & 0 & 0 & 237 & 0 & 0 & 0 \\
\hline Payment for private U.S. MOX fabrication & $\mathbf{0}$ & 2007 & 0 & 0 & 0 & 0 & 0 \\
\hline $\begin{array}{l}\text { Gross electricity revenues (government-owned } \\
\text { reactors) }\end{array}$ & $\mathbf{0}$ & 0 & 0 & 0 & 0 & -7888 & -7152 \\
\hline Revenue sharing (government-owned reactors) & $\mathbf{0}$ & 0 & 0 & 0 & 0 & 734 & 0 \\
\hline $\begin{array}{l}\text { Reactor salvage value (government-owned } \\
\text { reactors) }\end{array}$ & 0 & 0 & 0 & 0 & 0 & -2586 & -2242 \\
\hline \multirow[t]{2}{*}{ Total LCC } & 2224 & 2852 & 2424 & 2429 & 3351 & -1796 & 2609 \\
\hline & \multicolumn{7}{|c|}{ Discounted costs ( $1996 \$ M)$} \\
\hline Up-front (investment) cost for all facilities & 687 & 400 & 953 & 706 & 628 & 2187 & 4194 \\
\hline $\begin{array}{l}\text { Operations costs including transportation for } \\
\text { all facilities }\end{array}$ & 965 & 528 & 895 & 970 & 1080 & 1759 & 1733 \\
\hline D\&D costs for all relevant facilities & 83 & 62 & 147 & 89 & 84 & 131 & 78 \\
\hline Fee to reactor owners or contracted operators & 231 & 204 & 173 & 229 & 123 & 89 & 69 \\
\hline $\begin{array}{l}\text { Revenue from sale of MOX at uranium } \\
\text { equivalent price }\end{array}$ & -658 & -597 & -817 & -725 & -145 & 0 & 0 \\
\hline Payment for EuroMOX fabrication & 0 & 0 & 0 & 173 & 0 & 0 & 0 \\
\hline Payment for private U.S. MOX fabrication & 0 & 863 & 0 & 0 & 0 & 0 & 0 \\
\hline $\begin{array}{l}\text { Electricity revenues (government-owned } \\
\text { reactors) }\end{array}$ & 0 & 0 & 0 & 0 & 0 & -2975 & -2312 \\
\hline Revenue sharing (government-owned reactors) & 0 & 0 & 0 & 0 & 0 & 277 & 0 \\
\hline $\begin{array}{l}\text { Reactor salvage value (government-owned } \\
\text { reactors) }\end{array}$ & 0 & 0 & 0 & 0 & 0 & -628 & -519 \\
\hline Total discounted LCCs & 1308 & 1460 & 1351 & 1442 & 1770 & 840 & 3243 \\
\hline
\end{tabular}


Table 3. LCCs for hybrid reactor/can-in-canister vitrification options

\begin{tabular}{|c|c|c|}
\hline Facility/cost category description & $\begin{array}{c}\text { LWR hybrid } \\
\text { case }^{a}\end{array}$ & $\begin{array}{c}\text { CANDU hybrid } \\
\text { case }^{b}\end{array}$ \\
\hline \multicolumn{3}{|c|}{ Front-end facility costs (constant 1996 \$M) } \\
\hline Plutonium-processing up-front cost (for $50 \mathrm{MT}$ plutonium) & 343 & 343 \\
\hline Plutonium-processing 10-year operations cost & 823 & 823 \\
\hline Plutonium-processing D\&D cost & 159 & 159 \\
\hline MOX fabrication up-front cost (for $32.5 \mathrm{MT}$ plutonium) & 350 & 450 \\
\hline MOX fabrication operations cost & 711 & 1171 \\
\hline MOX fabrication D\&D cost & 50 & 70 \\
\hline Credit to DOE for displacement of uranium by MOX & -925 & -273 \\
\hline \multicolumn{3}{|c|}{ Back-end facility costs (constant $1996 \$ M$ ) } \\
\hline Hot-cell immobilization up-front (defense waste processing facility) & 222 & 222 \\
\hline Hot-cell immobilization 10-year operations cost & 52 & 52 \\
\hline Hot-cell immobilization D\&D cost & 2 & 2 \\
\hline Reactor-related up-front cost (incremental) & 205 & 99 \\
\hline Reactor-related operations costs (incremental) & 70 & 29 \\
\hline Incentive fee to reactor owner & 270 & 184 \\
\hline Reactor-related D\&D costs (incremental) & 0 & 0 \\
\hline Repository costs at $\$ 500 \mathrm{~K} /$ canister (immobilization) & 35 & 35 \\
\hline Incremental repository cost for spent MOX fuel & 0 & 0 \\
\hline Total undiscounted LCC & 2367 & 3366 \\
\hline Total discounted $\mathrm{LCC}$ at $5 \%$ discount rate & 1371 & 1867 \\
\hline
\end{tabular}

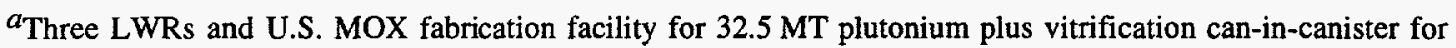
17.5 MT plutonium; PuP facility located in existing SRS F-area handles all $50 \mathrm{MT}$ plutonium.

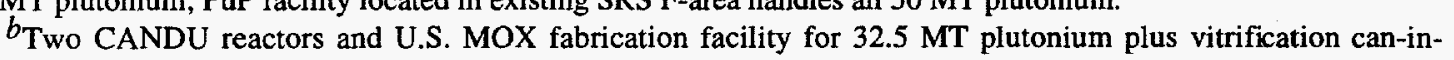
canister for 17.5 MT plutonium; PuP facility located in existing SRS F-area handles all $50 \mathrm{MT}$ plutonium. 


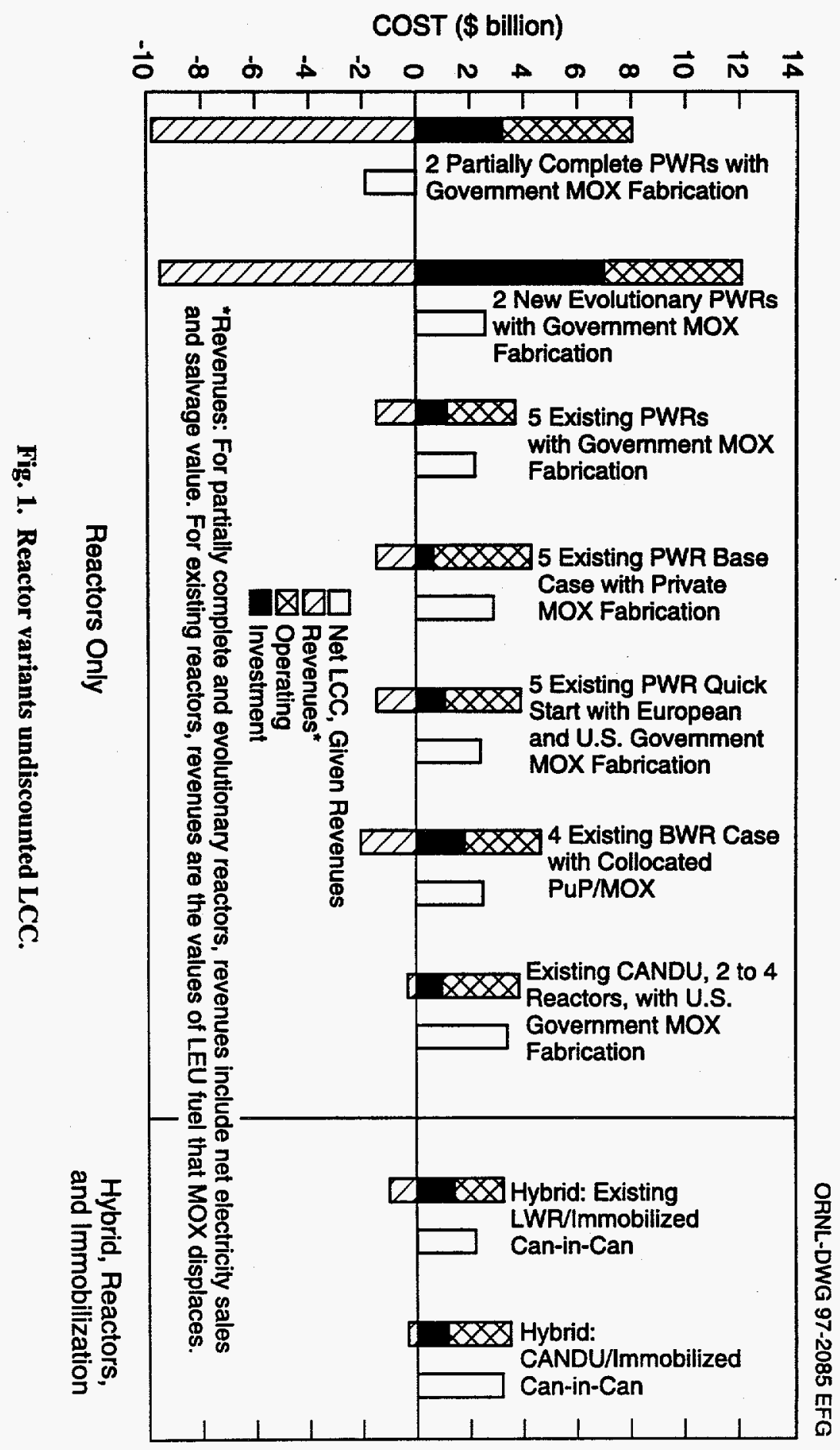




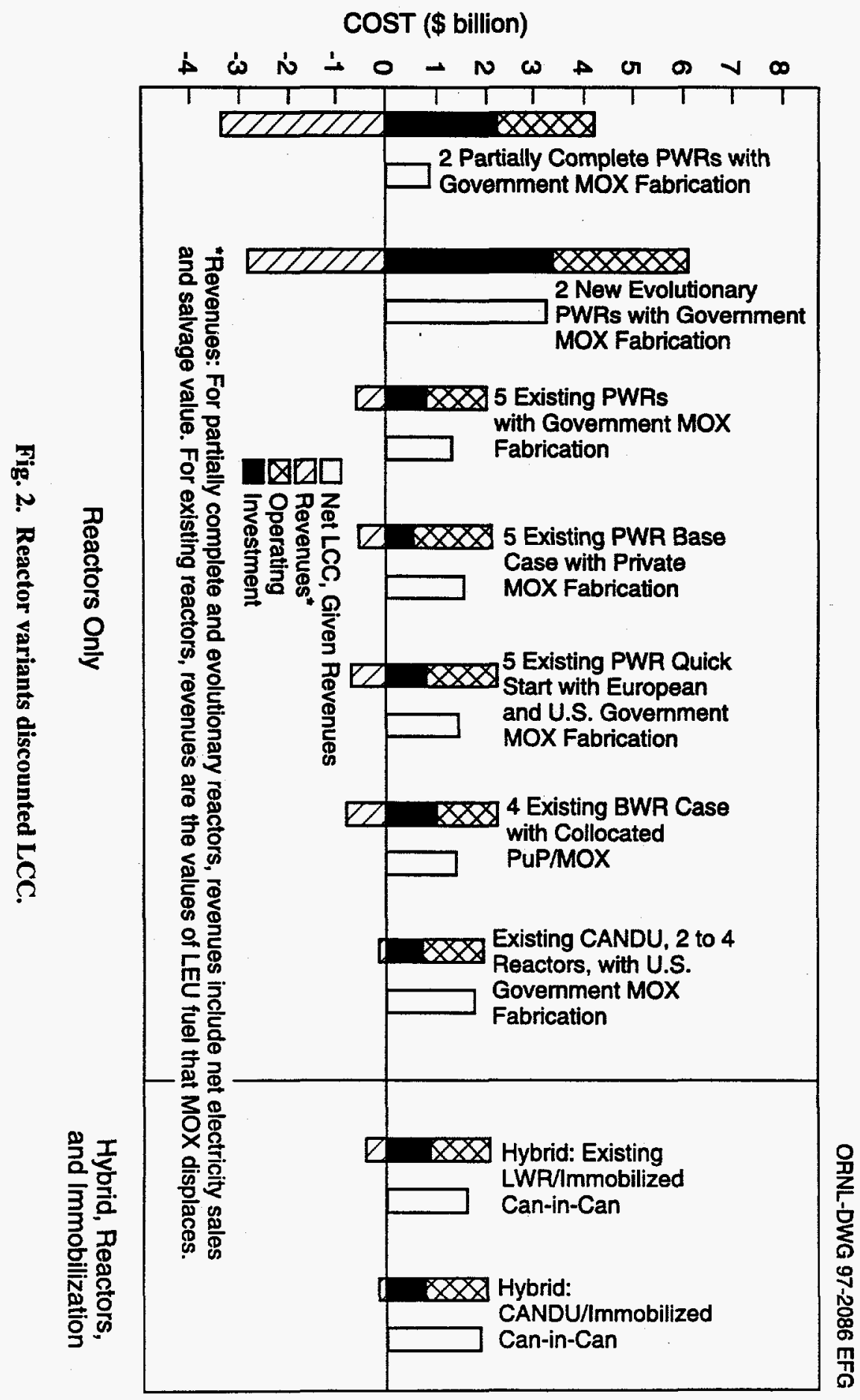




\section{COST UNCERTAINTIES IDENTIFIED BEFORE ROD}

The reactor disposition option using MOX fuel has few cost uncertainties related to technical factors. Most uncertainties are related to business arrangements (e.g., the incentive fees to utilities for irradiation services, possible increases in the repository fee for spent MOX fuel, and the need to pay for replacement power during reactor modifications). New government-owned reactors carry a very high cost risk because of the uncertain electricity revenues that would result in a highly deregulated electricity market where nuclear power is becoming less competitive. (This is the main reason this option was eliminated.) Other MOX cost uncertainties arise from the cost effects of schedule delays due to licensing and the possibility of legal intervention. Since many European reactors use MOX, there is no question that MOX use is technically and commercially feasible.

A brief summary of the cost values associated with these uncertainties affecting the existing reactors variant is included below. (See Ref. 5 for cost values associated with uncertainties for the other reactor variants.) The disposition of $50 \mathrm{MT}$ by the reactor/MOX option is assumed for all cases below.

\subsection{FEE FOR IRRADIATION SERVICES}

A fee for irradiation services was not included in the LCC values shown in Ref. 5 but is accounted for in Table 2 of this report. A typical value of the total disposition campaign fee for irradiation services for 50-MT plutonium is estimated to be about $\$ 500$ million. The actual values of the fee will result from negotiations with the selected reactor owner. (Depending on the business arrangement actually utilized, such as for a consortium under an "umbrella" contract, a fee may not even be necessary since LEU fuel savings may get factored directly into the contract.) The fee would depend on many variables, including the financial health of the company owning the reactor, the projected long-term cost of uranium fuels, exposure to financial and technical risks, local electric power conditions, ability to enhance shareholder value, and assessments of prospective competitors for the disposition mission. The net cost to the government, reflected in this report as a fee, will result from an integrated business arrangement with the reactor owners yet to be negotiated (see the program acquisition strategy).

\subsection{REACTOR MODIFICATIONS}

Although modifications to reactors are expected to be accomplished in a manner that does not impact the implementation of MOX fuel cycles beyond what is already included in the cost estimates of Table 2, an incremental 1-month shutdown for each of five reactors in the existing LWR variant is postulated. The government would be liable for $1200 \mathrm{MW}$ of replacement power for each of the five reactors for 1 month, which results in an estimated cost of $\$ 100$ million, based on a projected cost of energy of $\$ 29 / \mathrm{MWh}$.

\subsection{VARIATION IN THE MARKET PRICE FOR LEU FUEL}

The price a LWR utility pays for LEU fuel depends mainly on the cost of the uranium and the cost of enrichment services. The market price for fuel today typically varies from $\$ 1000$ to 1500 per kilogram heavy metal ( $\mathrm{kg} \mathrm{HM}$ ). The fuel credit to the government for displaced LEU fuel, used to generated the life cycle costs of Table 2, was based on $\$ 1193 / \mathrm{kg}$ HM for PWR fuel and $\$ 1214 / \mathrm{kg} \mathrm{HM}$ for BWR fuel. The cost impact for postulated variations in the price of LEU fuel rising to $\$ 1500 / \mathrm{kg} H M$ or falling to $\$ 1000 / \mathrm{kg} \mathrm{HM}$ will result in a cost variation to the government ranging from a savings (relative to the cost in Table 2) of $\$ 400$ million to an additional cost of $\$ 200$ million.

\subsection{HIGH-LEVEL WASTE REPOSITORY}

The fee for disposal of spent LWR fuel is specified in the Nuclear Waste Policy Act as $1 \mathrm{mill} / \mathrm{kWh}$. Although not expected, there may be some additional cost to the repository to enable it to accept the MOXderived spent fuel. For a postulated increase of one additional mill per kilowatt hour for spent fuel disposal, the cost to the government would increase $\$ 200$ million. 


\subsection{ADVERSE VARIATION IN FRONT-END PROCESS PARAMETERS}

A postulated increase of $10 \%$ in front-end processing cost, as designed, would result in an increased cost to the government of $\$ 100$ million. If the Advanced Recovery and Integrated Extraction System (ARIES)/Thermally Induced Gallium Removal (TIGR) processes prove to be incapable of generating plutonium powder to meet classification, morphology, or gallium concentration criteria, aqueous processing would be required. ARIES is an integrated "dry" system for converting plutonium weapons components into either plutonium metal or plutonium oxide using a hydride process. TIGR is a process employing heat to remove gallium from the plutonium powder. This scenario, employing aqueous processing, would likely result in an additional $\$ 100$ million penalty to the government (approximately $\$ 50$ million ARIES sunk cost and $\$ 50$ million for establishing an aqueous processing line) and a 2-year increase in schedule. Articles in the trade press have suggested that the cost could be as much as $\$ 250$ million or higher.

\subsection{MODIFICATION AND CONSTRUCTION COSTS}

A postulated cost escalation of $50 \%$ in the front-end facility, MOX facility, and reactor modification would result in an increased cost to the government of $\$ 500$ million. A $50 \%$ variation from the baseline cost would represent the approximate fidelity of the estimate shown in Table 2 and represents a reasonable basis for planning purposes for cost overruns. A 2-year delay in schedule is also assumed.

\section{COST ISSUES AFTER ROD}

\subsection{STAND-ALONE ARIES}

Following ROD, interest was expressed concerning the cost of producing plutonium powder using the dry ARIES and TIGR processes at a federal site, considering only the 32.5-MT plutonium pits and clean metal feed material needed for the reactor option in a hybrid or dual-track scenario. This separation of functions would allow the pits and clean metals to be processed at one location, such as at SRS or the Pantex site, and the other 17.5-MT plutonium feed materials (that may require more extensive purification) to be processed elsewhere, perhaps by aqueous means. SRS cost estimators provided a preliminary estimate that accomplishes the 32.5-MT dry pit and clean metal processing task by adding a pit conversion module to the already funded Actinide Packaging and Storage Facility (APSF) at SRS. The APSF is scheduled for completion in the year 2000. This arrangement, which uses the receiving and handling (and other) systems of the APSF, could be accomplished, based on the preliminary estimate, for a TPC of \$221 million (\$169 million for the APSF building and equipment and $\$ 52$ million for the pit processing module).

This value of $\$ 221$ million is for a federal location (SRS), collocated with a proposed line item facility (APSF). Cost for processing the $32.5 \mathrm{MT}$ of pits and clean metal at other sites would vary, depending on the available site infrastructure. This preliminary cost estimate for processing just the pits and clean metal is subject to validation by the LANL site A-E.

\subsection{COST ACCOUNTING FOR GOVERNMENT (IMMOBILIZATION) vs PRIVATE (MOX) PROJECT}

The ROD calls for a dual approach to dispose of the $50 \mathrm{MT}$ of weapons-usable plutonium. Part of the plutonium is to be immobilized in glass or ceramic, and part is proposed to be burned as MOX fuel in nuclear reactors. The immobilization option will be accomplished using funds tracked through usual government project accounting and estimating standards, whereas the MOX option will involve private industry, which will require accounting for return "of and on" any investment made by the consortium to fabricate and burn the MOX.

Under the immobilization option, the financial arrangement would be as in any typical DOE-financed program. The government would purchase directly (probably through one of the DOE site operations offices or existing $M \& O$ contractors) the materials, labor, and services needed to complete the mission. 
Separate contracts would be issued for various phases of the mission, such as plutonium preparation, vitrification, disposal, etc.

Under the MOX option, which includes private participation, several contractual financial arrangements might be proposed, such as (1) government-managed program with a typical DOE-financed operation, similar to the immobilization option above; or (2) a total privatization approach with a consortium financing the MOX facility and reactor modification (with funds flowing from the government to the consortium).

As discussed in the program acquisition strategy, a variation on the second of these approaches (i.e., privatization implemented through a consortium) is the government's preferred approach.

\subsection{EFFECTS OF OMB CIRCULAR A-11 REVISION (FULL UP-FRONT FUNDING BY CONGRESS)}

OMB Circular A-11 (Ref. 7) reaffirms the full funding policy for acquisition of fixed assets, such as a MOX fuel facility. Full funding (or up-front funding) means that the full amount of budget authority is available before initiation of or signing of any contract for acquiring the asset or any economically and programmatically separable segment of the asset. Background information indicates that good budgeting requires that appropriations for the full costs of asset acquisition be provided up front to help ensure that all costs and benefits are fully taken into account when decisions are made about providing resources. Reference 7 further states that when fixed assets are funded in increments, without certainty if or when future funding will be available, it can, and occasionally does, result in poor planning, acquisition of assets not fully justified, higher acquisition costs, cancellation of major projects, the loss of sunk cost, or inadequate funding to maintain and operate the assets. Application of this policy will help ensure against the cancellation of major portions of the MOX option of the FMDP once the activity is implemented.

Reference 7 also states that under the Federal Acquisition Streamlining Act (FASA), OMB is required to report on the cost, schedule, and performance goals for asset acquisitions and how well the agencies are meeting these goals. Baseline cost, schedule, and performance goals will be the standard against which actual work is measured. They will be the basis for the annual report to Congress required by FASA on variances of $10 \%$ or more from the cost and schedule goals and any deviation from performance goals. The cost goals are to be reviewed by the chief financial officer prior to inclusion in the budget submission. See Ref. 7 for more detailed information on this subject in general.

\subsection{FINANCIAL CRITERIA OF IMPORTANCE IN SELECTING A CONSORTIUM}

The following is a list of possible qualitative cost-related criteria, including metrics, for the evaluation of the irradiation and MOX fabrication portions of the consortium. These will be refined as the program acquisition strategy proceeds.

\subsubsection{Utility}

It is imperative that the utility chosen for the mission does not put the mission in jeopardy via forced premature shutdown of its reactor(s) due to economic factors or bankruptcy. For this reason, careful analysis of the financial condition of the utility should be undertaken. The following attributes of utility financial performance can be used as metrics for evaluation.

- Utility balance sheet-An indication of the utility's financial capability to operate under a privatization or semiprivatization procurement approach.

- Utility bond ratings-Same as previous item.

- Electricity production costs-Is the reactor likely to suffer premature shutdown due to noncompetitiveness?

- Ability to thrive in a deregulated electricity market-Can the reactor provide competitive power in a market where unit revenues are likely to fall or remain steady? 
- Utility's plan to address deregulation issues such as "stranded assets"-Will unrecoverable capital costs cause utility bankruptcy or abandonment of reactor assets?

- Utility/Public Utility Commission relationship-Is the state/local economic regulatory body likely to disallow recovery of stranded assets and increase probability of bankruptcy or premature plant shutdown?

For the proposal evaluation processes, some kind of numerical rating system can perhaps be developed based on qualitative assessments of these attributes.

\subsubsection{MOX Fabricator}

Data on the assets and liabilities of the MOX fabricator part of a consortium (including parent company, if applicable) should be provided. Also, the estimated share of the worldwide uranium and MOX markets (separately) possessed by the MOX fabricator could be indicated.

\section{DEVELOPMENT OF NEW COST ESTIMATES FOR MOX FABRICATION FACILITY}

Once the A-E has been chosen by each qualified consortium, a conceptual design of the MOX plant and an associated cost estimate may be completed by each. It is the intent of ORNL to issue cost-estimate guidelines to each bidder so the cost estimates for the MOX plant will be consistent and comparable among participants (i.e., they will use the same year for constant dollar costing, the same discount rate, etc.). Forthcoming procurement documents will consider conceptual design report requirements in more detail.

\section{REFERENCES}

Instructions for obtaining these references are contained in Appendix B.

1. FMDP Reactor Alternative Summary Report: Vol. 1-Existing LWR Alternative, ORNL/TM-13275/V1, Lockheed Martin Energy Research Corp., Oak Ridge National Laboratory, October 7, 1996.

2. FMDP Reactor Alternative Summary Report: Vol. 2-CANDU Heavy-Water Reactor Alternative, ORNL/TM-13275/V2, Lockheed Martin Energy Research Corp., Oak Ridge National Laboratory, September 1996.

3. FMDP Reactor Alternatives Summary Report: Vol. 3-Partially Complete LWR Alternative, ORNL/TM-1325/V3, Lockheed Martin Energy Research Corp., Oak Ridge National Laboratory, September 1996.

4. FMDP Reactor Alternatives Summary Report: Vol. 4-Evolutionary LWR Alternative, ORNL/TM-13275/V4, Lockheed Martin Energy Research Corp., Oak Ridge National Laboratory, September 1996.

5. Technical Summary Report for Surplus Weapons-Usable Plutonium Disposition (Rev. 1), DOEMD-003, U.S. Department of Energy, October 31, 1996.

6. National Academy of Sciences, Management and Disposition of Excess Weapons Plutonium, National Academy Press, 1994.

7. "Planning, Budgeting, and Acquisition of Fixed Assets," OMB Circular No. A-11, Part 3, Executive Office of the President, Office of Management and Budget, July 1996. 


\section{APPENDIX A: EXPLANATION OF 24 COST CATEGORIES}

This appendix is organized to explain the 24 cost categories used in the economic analysis of the mixed-oxide (MOX) option as discussed in this report.

\section{A.1 OPERATING-FUNDED PROJECT COST (OPC) CATEGORIES (PART OF FRONT-END COST)}

\section{Research and Development (R\&D)}

National Laboratory R\&D-This category covers the R\&D performed at Department of Energy (DOE) national laboratories supporting a facility within an alternative. Any irradiations or postirradiation examinations of MOX fuel performed at a DOE laboratory should be carried under the MOX plant facility R\&D category. The revised DOE-MD R\&D plan should be used as a data source where possible.

Private Vendor R\&D-Work done by vendors or utilities and reimbursed by DOE should be included in this category, even if subcontracted through a national Laboratory. Any irradiations done in all commercial reactors will fall in this category. This data should also be in the DOE-MD R\&D plan.

\section{National Environmental Policy Act (NEPA), Permitting, Licensing}

NEPA-This cost covers preparation of the site-specific environmental impact statement (EIS) [which follows the more generic programmatic environmental impact statement (PEIS)]. This work is generally performed by national laboratories and contractors.

Licensing-This category covers the legal and technical work needed to obtain the Nuclear Regulatory Commission (NRC) license to begin construction. Some technical work, such as safety documentation, would be performed by vendors or national laboratories. MD would also have to cover the costs of NRC staff for the various NRC reviews. If DOE licensing, such as Defense Facilities Nuclear Safety Board (DFNSB) review, is used, those costs should be reported here. Most of the cost in this case would be for studies and documentation prepared by vendors, laboratories, and management and operations (M\&O) contractors.

Permitting-This category is similar to licensing, except that the activities are geared to obtaining state, local, and federal permits related to air and water quality. Construction permits are also included in this category.

\section{Conceptual Design}

Design work performed prior to Title I design and funded out of the DOE operating budget falls in this category. Usually this work is performed by an architect-engineer (A-E) firm or by the resident engineering staff at an M\&O contractor site. Such a design is usually the first draft design using take-offs from drawings and equipment specifications and includes a cost estimate.

\section{Quality Assurance, Site Qualification, and Safeguards and Security (S\&S)}

Site Qualification-Once a site for a facility is recommended, it must be certified that the site geology, infrastructure, and meteorology is capable of safely accommodating the facility and any wastes or emissions generated from it. For geologic disposition options, this can be a lengthy and expensive step. The work is generally performed by DOE contractors or their subcontractors. Much of the work includes environmental and geologic sampling and documentation of findings.

S\&S-Prior to design, an S\&S plan must be generated to focus the facility design toward meeting domestic and international S\&S requirements. Most of these costs are incurred by DOE contractors (including M\&Os and laboratories) or their subcontractors.

Quality Assurance (QA) - Once the Record of Decision (ROD) is accomplished, a formal QA plan and organization must be put in place for the project and its various facilities. Much of the effort involves 
records management and assuring that all work is properly checked and documented to support regulatory processes. This work is normally done by a DOE contractor or a subcontractor to an M\&O contractor.

\section{Postconstruction Start-Up (Activities Prior to Normal Operations)}

Vendor Startup-Since much of the equipment in a facility is purchased from vendors, the vendor may need to be funded for supervising the start-up phase for his equipment. This is especially true for reactor nuclear steam supply system (NSSS) equipment.

M\&O Contractor Startup Activities Including Training-Prior to beginning normal operations, the operator of a facility, presumably an $M \& O$ contractor, must come up to speed on implementation of the facility processes. Technology and information transfers from vendors to the $M \& O$ are required. DOE orders and NRC requirements also require extensive training of M\&O staff, not only on technical operations, but also on the Environmental, Safety, and Health (ES\&H) aspects of facility operations.

Procedure Documentation and Manual Preparation-Current regulatory regimes require complete documentation of operational procedures prior to facility startup. Manuals for various process equipment items must also be prepared as part of this activity. Both vendors and M\&O contractors may be involved.

Operational Readiness Reviews-The facility project office must prove to NRC or DFNSB that the facility is ready to commence operations in a safe and environmentally benign manner. Considerable contractor and regulatory staff time may be required to prepare for and carry out these reviews.

\section{OPC Contingency}

This contingency represents the additional funds needed to cover uncertainties and risks associated with the above activities (such as activity scope and schedule risk and their cost effects). A confidence level must be specified for this contingency. Calculation of contingency is best done by a multivariable uncertainty analysis in which uncertainty distributions for various input factors, such as schedule duration and staffing level, are identified. Such calculations can be done within spreadsheets with commercially available software.

\section{A.2 TOTAL ESTIMATED COST (TEC) CATEGORIES (LINE ITEM OR CAPITAL PART OF FRONT-END COST)}

\section{Engineering, Design, and Inspection}

Title I Design-Title I design is the first line-item funded design effort for a facility and includes detailed drawings, bills-of-material, and craft labor requirements. A Title I cost estimate usually is also produced. An A-E firm is often used for this level of design effort. For reactors, the NSSS vendor may also play an important role. Several engineering disciplines are usually involved in the effort. The design at this point should be site specific.

Title II Design-Title II design produces the final preconstruction drawings, bill-of-material, and other specifications. The same A-E firm as for Title I design is often used. Title II normally utilizes more engineering-hours than does Title $\mathrm{I}$.

Title III-Title III is engineering that takes place during construction and involves verification that the Title II final design is being implemented. Inspection activities and QA are included in this category.

\section{Construction}

Direct Construction Costs-Direct construction includes the craft labor, direct supervision, materials (such as construction commodities; concrete, rebar, steel, etc.), and purchased equipment needed to construct the facility. In addition to process equipment, the following should be included: safety systems, S\&S systems, lag storage at the facility, waste processing equipment, and utility equipment. The cost of land is included here if necessary. Initial inventories of needed consumables, such as reactor cores, should be included in this category. 
Indirect Construction Costs-Indirects include overheads such as craft labor benefits, construction equipment rentals, temporary on-site offices for the craft subcontractors and construction supervisors, QA documentation and storage thereof, training of craftsmen, small tools and supplies, miscellaneous vehicles, and safety equipment.

\section{Construction Management}

For government-owned facilities, DOE usually hires a construction manager (CM) (normally an A-E firm) to handle the subcontracting of craft labor and to interact with the design A-Es and equipment vendors. Typically the CM's fee is around 5\% of the total of the direct and indirect construction costs.

\section{Initial Spares}

Initial spares are major and crucial extra equipment items purchased out of the project capital budget. These are items needed to ensure process operation in the event of the failure of a major piece of installed equipment. The nature and cost of these items is technology dependent.

\section{Allowance for Indeterminates (AFI)}

AFI is often called "contingency" by the A-E or vendor preparing the cost estimate and is used to account for labor and material/equipment items not anticipated by the preparer at the time of the estimate. Because it is often experience based, the AFI fraction is generally lower for a mature technology for which facilities have been built. When the vendor calculates AFI, he generally assumes that the project scope (i.e., plant size, feed rate, base unit operations flow sheet, etc.) does not change and that the project stays on schedule. Regulatory, schedule, R\&D, and design risk is not quantified here, but rather is in the risk contingency. Most vendors calculate AFI to a 50\% confidence level (i.e., there is a $50 \%$ chance that the sum of items 7-11 will not be exceeded).

\section{Risk Contingency}

Increased regulation and litigation make nuclear projects financially risky from a schedule perspective. Changing regulations also often mean that a design or project scope may change during design or even in the construction phase. The cost effects of such occurrences are best examined by a multivariable sensitivity analysis on those cost and schedule items subject to uncertainty. Such an analysis yields a risk S-curve which plots cumulative probability vs TEC. The estimator must pick a desired confidence level for the TEC, such as $75 \%$ assurance that a corresponding TEC will not be exceeded. The difference between this TEC and the baseline TEC (sum of items 7-11) is the "risk contingency" added. Risk contingency can be considered a sort of management reserve, which the project manager can use to cover unanticipated events and cost overruns caused by scope changes and schedule slippage. (Note: not all providers of cost information for the pre-ROD estimates included estimates for this category.)

\section{A.3 OTHER LIFE CYCLE COST CATEGORIES (RECURRING AND END-OF-LIFE)}

\section{Operations and Maintenance Staffing}

Direct Operations Staff-This category includes salaries plus fringe benefits for those persons directly associated with operations, such as chemical operators, reactor operators, production machinists, foremen, and technicians, plus their line supervision. Clerical and health physics support in the process area can be included here.

Direct Maintenance Staff-This category includes salaries plus fringe benefits for those persons directly associated with maintenance, such as chemical technicians, maintenance mechanics, machinists, electricians, foremen, technicians, etc., plus their line supervision. Clerical and health physics support in the maintenance areas can be included here. 
S\&S Staff-This category includes salaries plus fringe benefits for guards, accountability clerks, technicians, and those persons supporting international safeguards activities.

Other Indirect Staff-This category includes salaries plus fringe benefits for the plethora of other personnel needed to run the facility in a safe and environmentally compliant manner to meet all federal, state, and local regulations. Among the indirect staff would be medical personnel, cafeteria workers, accountants, QA clerks, engineers, R\&D staff (for poststartup, process improvement $R \& D$ ), human resources personnel, firemen, stores clerks, travel clerks, in-house ES\&H oversight personnel, secretarial pool, etc. Some of these functions may be shared with other facilities on a DOE reservation and their costs allocated on a fair basis. Some of the data for these categories may be expressed as a ratio against the number of direct staff.

\section{Consumables and Utilities}

Electric Power-The annual cost of purchased electric power is to be included here. If power is provided by an on-site government reactor, the value of the facility "house load" power should be noted. Net electric sales revenues are covered in category 21 . The unit cost of electricity will depend on the location of the facility.

Fuels, Steam, Water-Annual costs for natural gas, fuel oil, water, purchased steam, phones, and other nonelectric utilities are to be reported here.

Miscellaneous Purchased Replaceables and Parts-The cost of routine replacement items such as equipment parts, worker clothing, electronics, etc., are in this category. Parts purchased for assembly into a final product, such as metal pacers for MOX fuel rods, are also included.

Process Chemicals and Feedstocks-Chemicals or feeds to a process are costed here. These may include solvents, powder binders, depleted or natural uranium fuel, alloying metals, and chemicals. Maintenance chemicals should also be included here.

\section{Major Capital Replacements and/or Upgrades}

Sometimes major items included in the capital estimate (TEC) require replacement on a nonroutine basis. [A steam generator in a pressurized-water reactor (PWR) plant is an example.] DOE's Capital Assets Management Plan (CAMP) now requires replacements or upgrades to keep DOE facilities operating in a safe and effective manner. For nonreactor facilities, 3 to $5 \%$ of the facility TEC is needed annually on a levelized cost basis.

\section{Waste Handling and Disposal}

High-Level Radwaste/Spent Fuel-This category applies only to a reactor or geologic disposal option. It is essentially the operations of the government repository covered by the $1 \mathrm{mill} / \mathrm{kWh}$ charge for reactor spent fuel or a to-be-determined (TBD) charge for high-level waste (HLW) canisters going to the repository. The cost includes packaging and transportation to the repository.

TRU (Transuranic) Waste - Significant amounts of plutonium-contaminated waste are likely to result from plutonium processing and MOX fuel fabrication operations. This material will likely be sent to the Waste Isolation Pilot Plant (WIPP) for permanent disposal. A unit cost and barrel loading along with the amount of plutonium generated as a waste form will be needed to calculate the annual cost.

Mixed, Resource Conservation and Recovery Act (RCRA), and Toxic Waste-If the disposal cost of any substances in these categories is significant ( $\$ 0.5$ million/year), it should be reported in this category.

Low-Level Radwaste - Waste of this type is sent to special burial sites covered under regional lowlevel waste (LLW) compacts. The cost is typically levied on a dollar-per-cubic-foot basis.

\section{Oversight}

NRC Oversight-If the NRC (or another DOE regulator) is to be reimbursed for services, such as inspections, these costs should be reported here. 
Other Oversight-If state and local regulators are to be reimbursed for services, such as inspections, these costs should be reported here.

\section{M\&O Contractor Fees}

Most DOE-owned facilities are operated by an $\mathrm{M} \& \mathrm{O}$ contractor on an award- or fixed-fee basis. The fee is often on the order of $2 \%$ of annual reimbursed operating costs per year.

\section{Payments to Local Communities and Counties in Lieu of Property Taxes (PILT)}

PILT is paid at some DOE sites to make up for the fact that DOE facilities do not pay property taxes. At the same time, however, DOE facilities and their employees have significant impact on the need for schools, roads, etc. Presently, DOE does not have a formula for PILT. In the future, PILT may be needed to assure public acceptance of facilities. A PILT of one-half the M\&O contractor fee would probably be appropriate.

\section{A.4 END OF LIFE AND OTHER SPECIAL COSTS}

\section{Decontamination and Decommissioning (D\&D)}

It should be assumed that a DOE M\&O contractor and perhaps an A-E will shut down, decontaminate, and remove contaminated and junk equipment from the facility. The cleaned-out facility probably does not have to be demolished if it does not pose a radiation hazard. The D\&D cost should include disposal of contaminated or junked equipment to licensed disposal sites.

\section{Revenues}

For new government reactors, revenues would accrue to the government from the sale of electricity. The year-by-year rates in mills per kilowatt-hour are available from ORNL. Salvage value of governmentowned reactors, at the end of the plutonium disposition campaign, is accounted for here. Also, revenue from the sale of MOX in the existing reactors option is also accounted for here (this is the same as the fuel displacement credit).

\section{Government-Paid Subsidies or Fees to Privately Owned Facilities}

If a facility such as the MOX plant or reactor is privately owned, the government's payments or subsidy may not be made until the facility is operating. This cost must recover the owner's LCCs plus the investors' returns minus any sales revenues to the owner.

\section{Transportation of Plutonium Forms to the Facility}

Costs of transporting plutonium and MOX through the various phases of processing, fabrication, and irradiation are accounted for in this category. The cost estimate is based on transportation by safe, secure, trailers (SSTs) and tractors between the facilities. For the plutonium processing facility, the transportation cost is from the present plutonium storage site, at an existing DOE facility, to the location of the plutonium processing facility. For the MOX facility, the transportation cost is from the plutonium processing facility to the location of the MOX facility, and likewise, for the reactor facility, the transportation cost is from the MOX facility to the location of the reactor. The initial plutonium forms are assumed to be safely packaged by either Environmental Management (EM) or Defense Programs (DP) and are readily shippable.

\section{Storage of Plutonium Forms at Present DOE Facilities Prior to Plutonium Processing Facility}

Once the present plutonium (which is placed in stable, transportable forms, based on DFNSB Order 94-1) comes under DOE-MD custody, its storage costs at existing sites (prior to transportation to the plutonium processing facility) become a program cost. If this is the case, this category accommodates those 
annual costs. This cost should decrease with time as plutonium is processed into the disposition system. (For the pre-ROD estimates, this category was assigned zero value for all options.) 


\section{APPENDIX B: \\ HOW TO OBTAIN SELECTED DOCUMENTS}

This section identifies and describes how to obtain a number of relevant documents that concern this report and DOE's program for disposition of surplus plutonium.

\section{B.1 FMDP REACTOR ALTERNATIVE SUMMARY REPORT VOLUMES 1-4}

The following reports are available to the public from the National Technical Information Service, U.S. Department of Commerce, 5285 Port Royal Road, Springfield, VA 22161. These reports are available to DOE and DOE contractors from the Office of Scientific and Technical Information, P.O. Box 62, Oak Ridge, TN 37831; telephone (423) 576-8401.

Limited quantities can be obtained by contacting the ORNL Fissile Materials Disposition Program Office, P.O. Box 2009, Oak Ridge National Laboratory, Oak Ridge, TN 37831-8057; telephone: (423) 576-7101.

- FMDP Reactor Alternative Summary Report Vol. 1-Existing LWR Alternative, ORNL/TM-13275/V1, Lockheed Martin Energy Research, Lockheed Martin Energy Research Corp., Oak Ridge National Laboratory, October 7, 1996.

- FMDP Reactor Alternative Summary Report Vol. 2-CANDU Heavy Water Reactor Alternative, ORNL/TM-13275/V2, Lockheed Martin Energy Research Corp., Oak Ridge National Laboratory, September, 1996.

- FMDP Reactor Alternative Summary Report Vol. 3-Partially Complete LWR Alternative, ORNL/TM-13275/V3, Lockheed Martin Energy Research Corp., Oak Ridge National Laboratory, September, 1996.

- FMDP Reactor Alternative Summary Report Vol. 4-Evolutionary LWR Alternative, ORNL/TM-13275/V4, Lockheed Martin Energy Research Corp., Oak Ridge National Laboratory, September, 1996.

\section{B.2 DOCUMENTS AVAILABLE FROM DOE-MD}

The documents listed below can be obtained by contacting the U.S. Department of Energy, Office of Fissile Materials Disposition, MD-4, Forrestal Building, 1000 Independence Avenue, SW, Washington, DC 20585, in writing or by phone at (202) 586-5413. Documents are also available from the DOE-MD World Wide Web (WWW) page at http://web.fie.com/htdoc/fed/doe/fsl/pub/menu/any, although in some cases documents are only available in partial form.

- Record of Decision for the Storage and Disposition of Weapons-Usable Fissile Materials Final Programmatic Environmental Impact Statement, U.S. Department of Energy, Office of Fissile Materials Disposition, January 14, 1997.

- Available on the WWW at http://web.fie.com/htdoc/fed/doe/fsl/pub/text/any/doedn020.htm

- Technical Summary Report for Surplus Weapons-Usable Plutonium Disposition, Rev. 1, DOE-MD0003, U.S. Department of Energy, Office of Fissile Materials Disposition, October, 1996.

- Available on the WWW at http://web.fie.com/htdoc/fed/doe/fsl/pub/text/any/doedn013.htm

\section{B.3 DOCUMENTS AVAILABLE FROM NATIONAL ACADEMY PRESS}

The following NAS report is available from National Academy Press, 2101 Constitution Avenue, N.W., Box 285, Washington, DC 20055; telephone: (800) 624-6242 or (202) 334-3313. 
- Management and Disposition of Excess Weapons Plutonium, National Academy of Sciences, National Academy Press, 1994.

- The Executive Summary and much of the Recommendations section is available on the WWW at http://web.fie.com/htdoc/fed/doe/fsl/pub/text/any/pub3a.htm 
ORNL/TM-13425

Dist. Category UC-523

\section{INTERNAL DISTRIBUTION}
1. S. L. Byerly
2. B. S. Cowell
3. E. C. Fox
4. S. R. Greene
5. G. T. Mays
6. G. E. Michaels
7-8. J. W. Miller
9. D. G. O'Connor
10-11. R. L. Reid

\author{
12. P. L. Rittenhouse \\ 13. C. C. Southmayd \\ 14. D. J. Spellman \\ 15. V.S. White \\ 16. D. L. Williams, Jr. \\ 17. K. A. Williams \\ 18. Central Research Library \\ 19-20. ORNL Laboratory Records (OSTI) \\ 21. ORNL Laboratory Records-RC
}

\section{EXTERNAL DISTRIBUTION}

22-26. P. T. Rhoads, U.S. Department of Energy, MD-3, Forrestal Building, Room 6G-050, 1000 Independence Avenue SW, Washington, DC 20585.

27. J. J. Buksa, Los Alamos National Laboratory, P.O. Box 1663, MS-F628, Los Alamos, NM 87545.

28. T. Barr, U.S. Department of Energy, EPG, Argonne National Laboratory, 9800 South Cass Avenue, Argonne, IL 60439.

29. R. Selby, U.S. Department of Energy, EPG, Argonne National Laboratory, 9800 South Cass Avenue, Argonne, IL 60439.

\section{WWW DISTRIBUTION}

The FMDP Web site, with a list of other relevant topical reports, is located at the following URL:

http://www.ornl.gov/etd/FMDP/fmdpproc.htm 